senting the change in references-per-item (not the crude changes in references) with age. The terms item-consultation decay rates and item-citation decay rates have been suggested $^{3}$ for suitably corrected factors.

Similar considerations apply equally to the data for obtaining a Bradford set. One citation in 1970 to a periodical first published in 1965 is much more significant than to one first published in 1960 because there are twice as many volumes of the latter available to be cited. Applying a correction to the Bradford sets in the Journal of Ecology, to allow both for the age of the periodical title and for an item-citation decay rate of 0.95 (a preliminary value obtained from citations in the same journal), raised the Kendall rank correlation coefficient to 0.25 : but this is still not high enough to place much reliance on the predictive value of a Bradford set for ecological literature.

Scientists and librarians would therefore be wise to approach an optimum $P \%$ library with caution and to check that the data they use for measuring the relative value of parts of their stock are suitable for the purpose and consistent from one occasion to another. Until they have done so they should not take any irrevocable decisions on the basis of Bradford sets or ageing factors.

Yours faithfully,

A. SANDISON

National Reference Library of

Science and Invention,

Holborn Division,

25 Southampton Buildings,

London WC2A 1 AW

${ }^{1}$ Brookes, B. C., Nature, 232, 458 (1971).

${ }^{2}$ Krauze, Tadeusz K., and Hillinger, Claude, J. Amer. Soc. Inf. Sci., 22, 333 (1971).

${ }^{3}$ Sandison, A., J. Doc., 27, 197 and 189 (1971).

\section{Sex Discrimination}

Sir,--We were startled to read in your issue of October 29 (Nature, 233, xxii; 1971) an advertisement, placed by the Australian Atomic Energy Commission, describing a research post and ending with the statement "Female rates slightly less than male rate quoted". The fact that sex discrimination is still an official policy of the Australian government does not, in our opinion, absolve a private journal such as yours from the responsibility not to abet discrimination based on race, national origin, political or religious belief, or sex. We presume, for example, that Nature would not now accept advertisements that were discriminatory with respect to colour or religion. We look forward to a prompt and public statement by Nature of a new nondiscriminatory advertising code.

Yours faithfully,

$\begin{array}{ll}\text { Dayid Layzer } & \text { J. G. Danziger } \\ \text { Randy Levine } & \text { Fred A. Franklin } \\ \text { Martha E. } & \text { Richard J. Defouw } \\ \text { Schwink } & \text { A. K. Dupree } \\ \text { H. T. Doyle } & \text { Michael Zeilik II } \\ \text { Joseph H. Schwarz M. E. Cravens } \\ \text { J. E. Goad } & \text { Sandra M. Faber } \\ \text { Jean H. Goad } & \text { Suzanne McKeE }\end{array}$

Kurt S. Anderson Christopher I.

Dale F. Dickinson McKeE

Martha H. Liller David E. Harris

Ruth Mandalian Charles King ROBERT NOYES

Harvard College Observatory,

Cambridge,

Massachusetts 02138

\title{
Obituary
}

\section{Dr Colin Cadman}

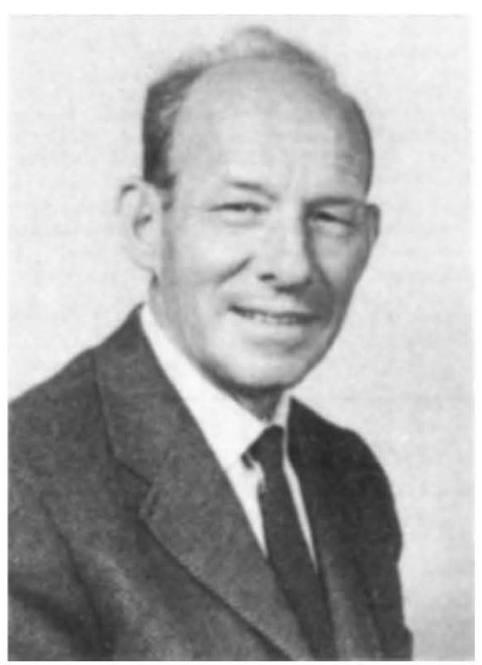

Colin Houghton Caiman, plant pathologist and Director of the Scottish Horticultural Research Institute, Dundee, died on September 27, aged 55.

After graduating from Liverpool University with First Class Honours in Botany he first worked at the Scottish Plant Breeding Station, Edinburgh, on the genetic control of the reaction of potato plants to virus infection. This work, which formed the basis of his $\mathrm{PhD}$ thesis, was the origin of his interest in plant viruses, and he devoted the rest of his productive research career to their study.

In 1943 the Scottish Raspberry Investigation, directed from East Malling Research Station, was set up at Dundee and Cadman became its resident pathologist. The main aim of this unit was to tackle the problems posed by the degeneration diseases of the raspberry, a crop more intensively grown in the area than anywhere else in the world. During the next eight years, by shrewd observation and simple experiments, he differentiated and identified many new viruses affecting raspberry and showed that some were spread by aphids. He began to propagate healthy stocks and became the foremost expert in raspberry viruses.

When the Scottish Horticultural Research Institute was founded in 1951, he became the head of its Plant Pathology Department and his research entered its most imaginative period. He discovered that a virus could be transmitted experimentally to herbaceous test plants by inoculating them with sap from raspberry plants affected by the important leaf curl disease. This led to the recognition of a group of viruses which cause ringspot symptoms in plants, have wide host ranges including numerous weed and crop species in many countries, and which spread through the soil. Following the American report that grapevine fanleaf virus has a-nematode vector he showed that arabis mosaic virus, one of the soilborne ringspot viruses found in Britain, is similarly transmitted; and that grapevine fanleaf virus can be sap-transmitted to herbaceous test plants and is serologically related to arabis mosaic virus. Other kinds of nematode-transmitted viruses were also found and one, tobacco rattle virus, was consistently obtained from potato tubers affected by spraign, a common disease that had previously defied efforts to determine its cause. A new field of plant virology was opened up and Cadman's laboratory became a centre of international repute for the study of soil-borne viruses.

$\mathrm{He}$ also did other pioneering work. He showed how to avoid the effects of substances that hindered the detection of viruses in woody species; he found a virus that was spread between raspberry plants, not by vectors but in pollen; and, independently of German workers, he showed that some isolates of tobacco rattle virus existed in plants as ribonucleic acid that was not protected by a protein coat.

His research having been the main foundation of the scientific reputation of the Scottish Horticultural Research Institute, he became its second Director in 1965. During the next six years he achieved a transformation. Research was reorganized to stimulate scientific productivity, and a comprehensive build- 
ing programme started to provide improved accommodation and modern facilities. He fostered closer links with the farming and processing industries, he set up the Institute Association to bring the two together and keep them informed of research results, and he did much to launch the Scottish Nuclear Stock
Association, which was founded initially to propagate the Institute's virus-free raspberry stocks for distribution to growers.

Colin Cadman had a quiet, sympathetic and perceptive but determined nature, and never took his decisions without careful thought. He gave much unselfish help to younger colleagues, and encouraged them to pursue problems in depth regardless of whether immediate practical applications were likely to result. In private life he was a good field botanist who loved the Scottish hills and was an accomplished cellist. He was not married but will be much missed by many friends.

\section{Announcements}

\section{University News}

Dr Alan Thompson, University of Edinburgh, has been appointed to the new chair of economics of government in Heriot-Watt University.

Dr M. H. Day has been appointed to the chair of anatomy tenable at St Thomas's Hospital Medical School and Dr C. D. Marsden has been appointed to the chair of neurology tenable at the Institute of Psychiatry and King's College Hospital Medical School, University of London.

Professor Richard Lynn has been appointed to the chair of psychology at the New University of Ulster.

\section{Appointments}

Lord Orr-Ewing has been appointed deputy chairman of the Metrication Board.

\section{Errata}

THE title of the article by V. P. Starr (Nature, 233, 186; 1971) should be "Eddy Viscosity and the Solar Rotation".

IN the article "Cyclic Expression of Blood Group Determinants in Murine Cells and their Relationship to Growth Control" by D. B. Thomas (Nature, 233, 317; 1971), the abscissa to Fig. 2 should read: "Hours after release of double thymidine block".

\section{Reports and Publications}

not included in the Monthly Books Supplement

\section{Great Britain and Ireland}

The Science of Botany: From Simple Lore to Social Need. By Professor A. G. Morton. (Inaugural Lecture, 15th March 1971.) Pp. 18, (London: Chelsea College, University of London, 1971.

Annual Report of the Meteorological Office 1970 Pp. xii + 102. (London: HMSO, 1971.) 80p net. [168 Department of the Environment. Water Pollution Research 1970: The Report of the Water Pollution Research Laboratory Steering Committee with the Report of the Director of Water Pollution Research p. vii +185 . (London: HMSO, 1971.) £1.15 net. [178 Department of Education and Science. On Course (London: Department of Education and Science, 1971.) [178 County Councils Association; Association of Municipal Corporations; Urban District Councils Association; Association of Public Analysts. Joint Survey of Pesticide Residues in Foodstuffs sold in England and Wales, 1st August, 1967-31st July, 1968 (second year). Pp. 38. (London: Association of Public Analysts, 1971.) 11.10 (including postage). [188 Oundle School Natural History Society. Annual Report 1970. Pp. 55. (Oundle, Peterborough: Oundle
School, 1971.)

Foreign and Commonwealth Office-Overseas Development Administration. Directorate of Overseas Surveys Annual Report for the year ended 31st March 1970. Pp. 69+8 photographs +9 maps. (London: HMSO, 1971.) £1.20 net.

Ministry of Agriculture, Fisheries and Food. Technical Bulletin No. 24: The Significance of Winte Rainfall Over Farmland in England and Wales. Pp. vii +69. (London: HMSO, 1971.) 45p net. [208 Central Statistical Office. Statistical News No. 14 Developments in British Official Statistics. Pp. v+26 (London: HMSO, 1971.) 30p net.

\section{Other Countries}

Pharmaceutical Manufacturers Association Foundation, Inc. 1970 Annual Report. Pp. 30. (Washington, DC: Pharmaceutical Manufacturers Association Foundation, Inc., 1971.)

Bulletin of the American Museum of Natura History, Vol. 144, Article 5: A Review of the PrePliocene Penguins of New Zealand. By George Gaylord Museum of Natural History, 1971.) \$2.50. American Mutation Breeding for Disease Resistance. (Proceedings of a Panel on Mutation Breeding for Disease Resistance organized by the Joint FAO/IAEA Division of Atomic Energy in Food and Agriculture and the FAO Plant Production and Protection Division and held in Vienna, 12-16 October 1970. Panel Pro ceedings Series.) Pp. 249. (Vienna: International Atomic Energy Agency; London: HMSO, 1971.) 155
schillings; $£ 2.50 ; \$ 6$.

Commission on Undergraduate Education in the Biological Sciences. Publication No. 32: Guidelines and Suggested Titles for Library Holdings in Undergraduate Biology. Edited by Joan Creager. Pp. iv +65 . Education in the Biological Sciences, 3900 Wisconsin Avenue, NW, 1971.) gratis. The Year Book of the International Council of The Year Book of the International Council of
Scientific Unions 1971. Pp. 241. (Rome: ICSU, Scientific Unions 1971. Pp. 241. (Rome: ICSU,
[98 FAO-WHO-OIE. Animal Health Yearbook 1970. Pp. 334. (Rome: FAO; London: HMSO, 1971.)
£1.60; \$4; FF20. Environmental Physiology: Nutrition, Pollution, Environmental Physiology: Nutrition, Pollution,
Toxicology, Vol. 1, No. 1, 1971. Edited by J. Clausen. Pp. 1-54. Subscription price: D.kr. 148.00 plus postage D.kr. $12.00(\$ 21.50)$ payable in advance. Price per issue D.kr. 40.00 (\$5.40). (Copenhagen: Munksgaard,
[118 Smithsonian Contributions to Zoology. No. 63 : Bredin-Archbold-Smithsonian Biological Survey of Dominica-The Dermaptera (Earwigs) of Dominica. By Alan Brindle. Pp. 25. \$0.40. No. 81: The Entocytherid Ostracods of Mexico and Cuba. By Horton . pods of the Family Chondracanthidae from Fishes of \$0.50 (Washington DC: Su-shey Ho. Pp. 39. Press, 1971. For sale by US Government Printing Office.) Record of the South Australian Museum, Vol. 16 No. 7: Acarine and other Microfossils from the Maslin Eocene, South Australia. By $R$. Southco t and R. T. Lange. Pp. 21. (Adelaide: South Australian US Department of the Interior: Geological Survey. Water-Supply Paper 2001-A: Ground-Water an Geohydrologic Conditions in Queens County, Lon Island, New York. By Julian ISoren. Pp. iv $+39+$ plates (Washington, DC: Government Printing
Office, 1971.) Canada: Department of Energy, Mines and $\mathrm{Re}$ sources. Geological Survey of Canada. Bulletin 174 Geochemistry of Iron, Manganese, Lead, Copper Zinc, Arsenic, Antimony, Silver, Tin, and Cadmium By. W Prons By E. W. Presant. Pp. 93. \$2. Paper 71-1: Report of Pp. vit 39 . 2 Paper 71-18. Secondary Fields of Pp. vi +139 . \$2. Paper 71-18: Secondary Fields of Layer of Conductive Overburden. By A. V. Dyck and Layer of Conductive Overburden. By A. V. Dyck and A. Becker. Pp. $v+25$. \$1.50. (Ottawa: Information Annual Report of the Inter-American Tropical Annual Report of the 127. (La Jolla, California Tuna Commission 1970. Pp. 127. (La Jolla, California: Organisation for Economic Co-operation and Development. Science, Growth and Society: a New Perspective. Pp. 113. (Paris: OECD, 1971.) 10 francs;
$77 \mathrm{p} ;$ \$2.25; 9 Sw. francs; 7 DM.

\section{HOW TO BUY NATURE}

Volumes start in January, March, May, July, September and November, but subscriptions may begin at any time. The direct postal price per subscription is :

12 MONTHS* (52 issues per title)

$\begin{array}{lcc} & \begin{array}{c}\text { Surface Mail } \\ \text { UK and } \\ \text { worldwide }\end{array} & \begin{array}{c}\text { Airfreight } \\ \text { U.S.A. \& Canada }\end{array} \\ \begin{array}{l}\text { Nature (Friday) } \\ \text { Nature+ } \\ \text { Nature Physical Science }\end{array} & £ 14 & \$ 48 \\ \begin{array}{l}\text { Nature+ } \\ \text { Nature New Biology }\end{array} & £ 24 & \$ 83 \\ \text { All three editions } & £ 29.50 & \$ 83 \\ \text { Annual Index } & £ 1 & \$ 108\end{array}$

- Rates for shorter periods pro rata (minimum three months) (Charge for delivery by air mail on application)

\section{Editorial and Publishing Offices of NATURE}

MACMILLAN JOURNALS LIMITED 4 LITTLE ESSEX STREET, LONDON WC2R 3LF

Telephone Number: 01-836 6633. Telegrams: Phusis London WC2R 3LF Telex: 262024

711 NATIONAL PRESS BUILDING WASHINGTON DC 20004

Telephone Number: 202-737 2355. Telex: 64280 Subscription Department

MACMILLAN JOURNALS LIMITED

BRUNEL ROAD, BASINGSTOKE HANTS

Telephone Number: Basingstoke 29242 American display advertisements

NATURE SCIENTIFIC PUBLICATIONS INC.

711 NATIONAL PRESS BUILDING WASHINGTON DC 20004 All other advertisements

T. G. SCOTT \& SON, LIMITED

1 CLEMENT'S INN, LONDON WC2A 2ED

Telephone 01-242 6264/01-405 4743

Telegrams: Textualist London WC2A 2ED

Registered as a newspaper at the Post Office

Copyright (C) Macmillan Journals Limited, December 101971 